\title{
掌面の接触状態遷移を用いた物体操作の慣れと疲れの評価*
}

$$
\begin{aligned}
& \text { 近藤誠宏*1, 上田淳*2 } \\
& \text { 松 本吉 央*1, 小笠原 司*2 }
\end{aligned}
$$

\section{Evaluation of Manipulative Familiarization and Fatigue Using Contact State Transition on Palm Surface}

\author{
Masahiro KONDO, Jun UEDA, \\ Yoshio MATSUMOTO and Tsukasa OGASAWARA*3 \\ ${ }^{* 3}$ Graduate School of Information Science, Nara Institute of Science and Technology, \\ 8916-5 Takayama-cho, Ikoma-shi, Nara, 630-0192 Japan
}

\begin{abstract}
In this research, we propose a method for generating a template used for the recognition of manipulation in consideration of the familiarization and the fatigue. We made a system that can evaluate a quantitative comparison of the similarity among manipulations performed by observing the contact state transition on the palm surface. This system can detect the contact state on the palm surface by attaching a tactile sensor sheet on the manipulated object. In the experiment, the familiarization and the fatigue are detected by measuring the variance of manipulation. The experimental result indicates that manipulation is able to be divided into three terms, which are the proficiency process, the familiarization and the fatigue. It is also indicated that the variation of the manipulation becomes small when the template is genarated by the manipulation data in the familiarization term.
\end{abstract}

Key Words: Manipulation, Teaching, Fatigue, Familiarization, Tactile Sensor

\section{1.は じめに}

多指多関節を持つロボットハンドは構造が複雑であ るため, ティーチングプレイバックやタスクプログラ ミングに代表される従来の単純な教示法の適用は困難 である. そこで人間の動作の観察から多指ハンドの教 示入力を行う手法が提案されている ${ }^{(1)}$. この直接教示 入力は多関節の入力を直感的に, かつ一度で行えるた め多指ハンドの入力手法として有効である. しかし， 教示者の手と多指ハンドの間に構造上の差がある場合, 単純な教示データの転送では作業を正確に遂行できな い，そのため，操作認識により抽象的な操作の情報を 取得し，そこから動作計画を立てる手法が求められる. 操作認識は一般的に予め操作のテンプレートを用意し, 操作者の入力と比較することで行なう. 正確な認識の ために，操作の詳細な特性を解析し，テンプレートを 生成することは重要な課題である. 人は物体操作に対 し慣れや疲れが生じるため, 操作の進行に従い操作方 針やそのばらつき度合いが変化する. よって, 慣れや 疲れによる変化を考慮したテンプレートの生成が必要 である.

\footnotetext{
* 原稿受付 2005 年 9 月 26 日。

*1 奈良先端科学技術大学院大学情報科学研究科 (画 630-0192 生駒市高山町 8916-5).

*2 正員, 奈良先端科学技術大学院大学情報科学研究科,

E-mail : ogasawar@is.naist.jp
}

人間の日常操作では, 物体把握後に環境に接触させ ることなく指の動きや掌を利用して把握変更や物体姿 勢位置の調節を行なっている.このような操作は“手 内操作 (In-hand manipulation)" と呼称され，操作の一 形態として定義されている ${ }^{(11)}$. 例えば, 片方に打撃面, 片方に釘抜きを持つネールハンマーは手内操作によっ て持ち替えることで二つの機能を切替えている. 携帯 電話ではボタン操作と通話で把握位置が異なり, 手内 操作で持ち替える必要がある. 上記の持ち替え作業は ピックアンドプレースの組み合わせでも実現可能であ る. しかし, 人間は作業環境の制限や作業時間短縮の ために手内操作を選択していると考えられる.

手指で行なう操作の慣れや疲れに関する研究はいく つか報告されている．Liu $5^{(3)}$ は筋肉疲労と脳の活動 の関係を調べ, 疲労が増加すると作業を維持する意思 がより強くなることを示した. Lin ${ }^{(4)}$ はタイピング 作業における腕の複数の筋肉疲労を計測し, 指の屈曲 よりも伸展の方が腕の疲労が大きいことを示した. ま た, 田口ら ${ }^{(5)}$ は円筒回転させる繰り返しタスクについ て解析を行い, 慣れによって運動制御がフィードバッ クからフィードフォワードへ移行するとの考察を得て いる.これらの研究では, 慣れや疲れ及びそれに伴う 現象を確認しているに過ぎず，現れた特徴を考慮して テンプレートを生成し, 認識等に生かす試みはなされ 


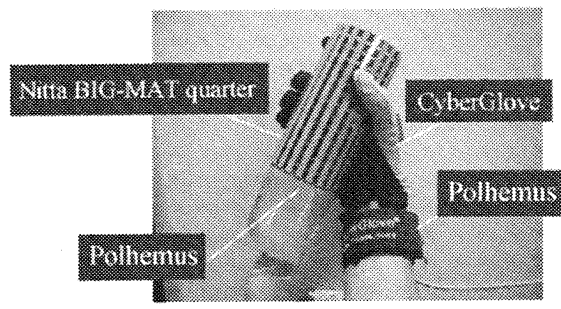

Fig. 1 Operation measurement system ていない.

一方, 従来の操作認識の研究では, VR 環境内で仮 想の被把握物体を用いて作業を行う多指ハンドの教示 システムが報告されている(6)(7)(8). また, 多眼のカメ ラを用いて物体や手の位置姿勢を測定して操作を観察 する研究も行われている(9)(10). これらの研究では一つ の操作に対するテンプレートが固定であり, 慣れや疲 れによる操作の変化は一切考慮していない. また, こ れらはピックアンドプレースやペグインホール等の単 純なタスクを対象としている. 手内操作等の複雑な操 作の認識にはより詳細な操作の解析からテンプレート を生成することが必要となる.

前報 ${ }^{(2)}$ では, 掌面の接触状態遷移を観察することで 操作の特徴を検出するシステムを構築した，また，連 続 DP マッチングを用いることで, 教示者が行った操 作の接触状態遷移パターン間の類似性を定量的に評価 する手法を提案した，本論文では，慣れや疲れを考慮 した操作認識のテンプレートを生成することを提案す る. まず, 操作認識システムを用いて時間の経過に伴 う操作の分散の変化を計测し, 被験者の操作に対する 慣れや疲れの検出を行う. そして, 操作を習熟・慣れ・ 疲れの 3 つの時間帯に分割し, 各時間帯毎に 3 つのテ ンプレートを生成することで入力操作との相関を計測 し考察する. その結果, 慣れの区間から生成されたテ ンプレートを用いるのが最も有効であることを示す. 本論文の対象タスクは手内操作とする. ただし，1つ の被操作物体を用いた片手での操作を対象とする. ま た, 操作中に掌面の接触状態が変化し, かつ手の姿勢 の変化が伴うことを前提としている，例えば, 指の接 触状態を変化させず, 把持力だけを変化させる動作は 対象としない.

\section{2. 作業計測システム}

掌面の接触状態遷移を観察する手法として, 掌面全 体に圧力分布センサを貼り付ける方法が考えられる. しかし，この手法では操作中の指の屈曲による圧力分 布センサの誤反応が非常に多く発生する. そこで, 図 1 のように被操作物体に圧力分布センサを取り付けるこ

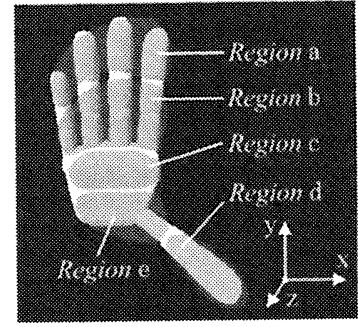

Fig. 2 Simple division of the palm surface とで掌面の接触状態を計測する作業計測システムを用 いる. オペレータは関節角度センサ (CyberGlove) と 6 軸位置姿勢センサ (Polhemus) を手に装着する．また， 被操作物体には圧力分布センサシート (NITTA BIGMAT quarter) と Polhemus を取り付ける.なお，本稿 では円柱物体の側面のみに圧力分布センサを装着する ため, 手が円柱の上面や底面との接触を伴うような把 握及び操作は扱わない.

この作業計測システムを用いて掌面の接触状態を検 出する. 検出は圧力分布センサから得られる物体の接 触点位置と, CyberGlove 及び Polhemus から得られる リンクの位置を比較することで行なわれる.

\section{3. 接触状態遷移の類似性計測}

本論文では，片手での手内操作を対象として認識を 行うが, 考えられる全ての物体形状と操作を扱うこと は対象が広過ぎるため困難である，そこで，以下の制 限をおいて物体形状と操作方向を限定することで接触 状態の数を抑え, 提案する認識手法の基礎的特性を確 認する.

(1) 操作物体は円柱とする

(2) 手が円柱の側面のみに接触する

(3) 操作中は図 2 の $\mathrm{x}$ 軸と円柱軸が常に平行 (3) の制限は操作に伴う物体の運動が y,z 軸方向の並進 及び $\mathrm{x}$ 軸周りの回転のみに限定すると言い換えること ができる. 上記の制限下では，示指〜小指の四指の働 きが同一となるため詳細に区別する必要性は低いと考 える，そこで，四指の末節を一つの領域に統合し，同 様に四指の中節と基節についてもそれぞれ統合する. さらに, 同様の理由で掌部も上半掌と下半掌にそれぞ れ統合する. また, 四指の PIP 及びDIP 関節はほぼ同 調して伸展屈曲すると認知されている．2つの関節で 1 自由度と考えると, 中節・基節を区別しても状態遷 移の特徴が現れることは少ないと判断し, 四指中節・ 基節を統合する.これらの統合の結果, 図 2 に示す単 純な領域分割を用いる. 図 2 の領域 $\mathrm{a} \sim \mathrm{e}$ はそれぞれ 四指末節部, 四指中基節部, 上半掌部, 拇指末節部, 下半掌部を表しており, 各領域の接触の有無から接触 

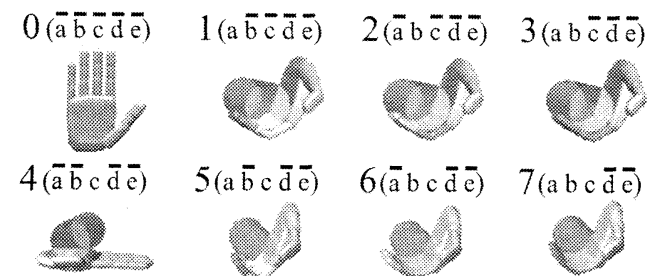

$8(\bar{a} \bar{b} \bar{c} d \bar{e})$

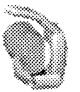

$12(\bar{a} \bar{b} c d \bar{e})$

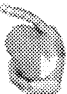

$16(\bar{a} \bar{b} \bar{c} \bar{d} e)$

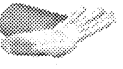

$20(\bar{a} \bar{b} c \bar{d} e)$

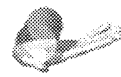

$21(a \bar{b} c \bar{d} e)$
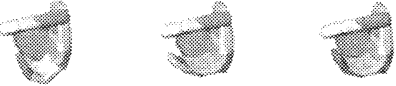

$24(\bar{a} \bar{b} \bar{c} d e) 25(a \bar{b} \bar{c} d e) 26(\bar{a} b \bar{c} d e) 27(a b \bar{c} d e)$
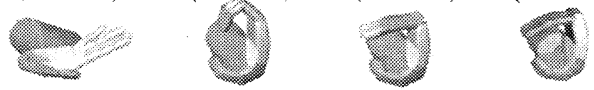

$28(\bar{a} \bar{b} c d e)$
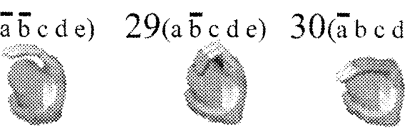

Fig. 3 All contact states

状態を定義する. 図 3 に本論文で扱う全ての接触状態 を示す. 図中の各状態番号の右横には掌面の各部位に おける接触の有無を論理記号で表している．例えば， a は四指末節部が接触していることを表し, ā は接触 していないことを表す．また，円柱を把握する手につ いては接触を伴う領域が網掛けで表現されている．同 じ接触状態であっても手形状が多少変化することがあ るため, 各接触状態の手形状は一意に決定しない，図 中には手形状の一例が表現されていることに注意され たい.

$3 \cdot 1$ 連続DPマッチング＼cjkstart物体操作は接触状態の 遷移によって表現される. 各タスクの標準的なパター ンである認識のためのテンプレートは，始点終点を持 つ有限な接触状態列で表される，それに対し，操作者 による入力パターンは連続的な接触状態列で入力され る.この 2 つのパターン間の類似度の計測は連続 DP マッチング(12)を用いる.

最新の入力を操作の終端と仮定した入力パターンと
標準パターンとの累積距離を $S\left(t_{s}, \tau\right)$ とし，以下の漸 化式で更新する.

$$
\begin{aligned}
& t_{s}=1,2, \ldots \\
& S\left(t_{s}, \tau\right)= \\
& \min \left\{\begin{array}{l}
S\left(t_{s}-2, \tau-1\right)+2 d\left(t_{s}-1, \tau\right)+d\left(t_{s}, \tau\right) \\
S\left(t_{s}-1, \tau-1\right)+3 d\left(t_{s}, \tau\right) \\
S\left(t_{s}-1, \tau-2\right)+3 d\left(t_{s}, \tau-1\right)+3 d\left(t_{s}, \tau\right)
\end{array}\right.
\end{aligned}
$$

ここで $t_{s}, \tau$ はそれぞれ入力, 標準パターンのサンプリ ング時間である. また, $d\left(t_{s}, \tau\right)$ は入力, 標準パターン 内の一つの接触状態間を比較した局所的な距離である. これは図 3 に示す各状態の論理記号を比較し, その差 から計算される.上記の漸化式によりパターン間で部 分的な伸縮を考慮した最も距離の小さい最適対応が計 算される. 連続 DP マッチングの出力 $A\left(t_{s}\right)$ は次式で 示される.

$$
A\left(t_{s}\right)=\frac{S\left(t_{s}, T\right)}{3 T}
$$

ここで $T$ は標準パターンの状態列の長さである. $A\left(t_{s}\right)$ は 2 つのパターン間の distance を表しており，これが 小さいほど類似度が高いことを表している.

この手法の利点はパターン内の部分的な伸縮を考慮 しながら相関をとることができる点にある．また，全 ての標準パターンと入力パターンの間でパターンマッ チングと始点位置検出を同時に行うスポッティング認 識が可能であるため, 本手法の操作認識に適している.

\section{4. 慣れと疲れの検出と解析実験}

4.1 実験内容 最初の実験では時間の経過に伴 う被験者の慣れや疲れの検出を試みる.被験者に慣れ が生じると, 操作中はより一定のパターンに近づき, その後に疲れが生じると, 一定の操作を維持できなく なると予測できる．よって，検出は操作のばらつきの 変化を計測することで行なう. 二つ目の実験では慣れ や疲れを考慮したテンプレートを生成するために, 習 熟期間・慣れ・疲れの3つの期間でそれぞれテンプレー 卜を生成し，大力パターンとの比較を行なう。なお被 験者は $\mathrm{I} \sim \mathrm{V}$ の 5 人とし， 3 種類のタスクで行う. 各 タスクの試行回数は一回とする. また, 疲労蓄積によ る影響を防止するため同一被験者による別タスクの試 行は 24 時間以降に行なう.

連続 DP マッチングで用いるテンプレートは, 事前 に実験とは別に複数の被験者から操作データを多数取 得し, 接触状態パターンの平均を計算することで生成 している. 図4 の例は，3つの接触状態パターンから 平均を計算している．まず，連続 DP マッチングを用 いてパターン間の最適対応を導き出し, 結線する. 各 


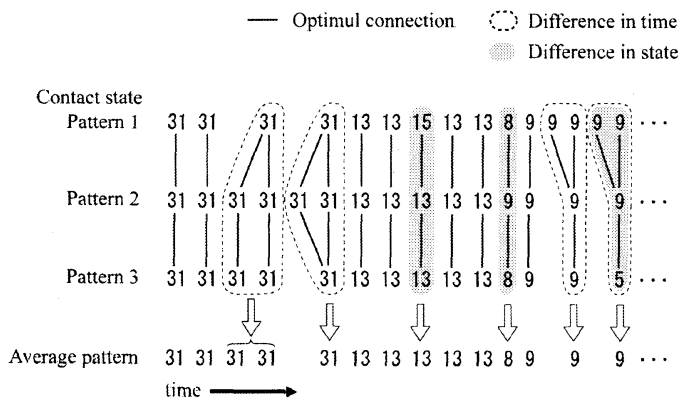

Fig. 4 Generation of the average pattern

対応間で時間の差や状態の差が存在する部分は, 各接 触部毎に多数決で平均の状態を決定する. 本実験では, テンプレートは実験と同一の被験者 $\mathrm{I} \sim \mathrm{V}$ の操作デー タから生成する. 類似度の計測は, このテンプレート と被験者の入力パターンとの間で行う. 実験の様子を 図 5 に示す.

また, 類似度計測の結果と比較するために, 被験者 の表面筋電を併せて計測し筋疲労を評価する. 筋電計 の電極の取り付け位置を図 6 に示す. 計測する筋肉は (1) 長掌筋, (2) 短拇指外転筋, (3) 総指伸筋の 3 種類 である. 動的な筋活動における筋電データからの疲労 度解析には周らの手法を用いた ${ }^{(14)}$. 筋肉が疲労すると 乳酸が発生し, それが中枢神経からの活動電位の伝導 速度を低下させる.この現象により筋電図スペクトル は低周波数へ移行する. よって, 表面筋電の中間周波 数を計測することにより筋疲労の計測を行うことがで きる. 急速な運動を伴う操作の筋電データはホワイト ノイズを含み非定常性を示すため, FFT を用いたスペ クトル解析は周波数バイアスやスペクトルき裂現象が 生じるので困難となる. そのため前処理として自己回 帰モデルを用いたノイズの推定により除去を行い，筋 電図スペクトルを計算する.

$4 \cdot 2$ 実験のタスク 手内操作である以下の 3 種 類のタスクについて実験を行った.

タスク $a:$ Heavy wrap $\rightarrow$ Prismatic grasp の持ち替え タスク $b:$ Prismatic grasp $\rightarrow$ Heavy wrap の持ち替え タスク $c$ : 円柱軸回転 (図 7(c) 向かって時計回り)

図7に各タスクの連続写真を示す. また, 代表的な一名 の被験者が各タスクを行った際の接触状態列を図 8 に 示す.ここで Heavy wrap, Prismatic grasp は Cutkosky による把握の定義を用いている(13). これらの把握は, それぞれの目的を担う代表的なものとして挙げられる. Heavy wrap(接触状態 31) は手で物体を固定するため の把握である. Prismatic grasp(接触状態 9,10,11) は指 先で把握し, 器用に操るための把握である. タスク $a$

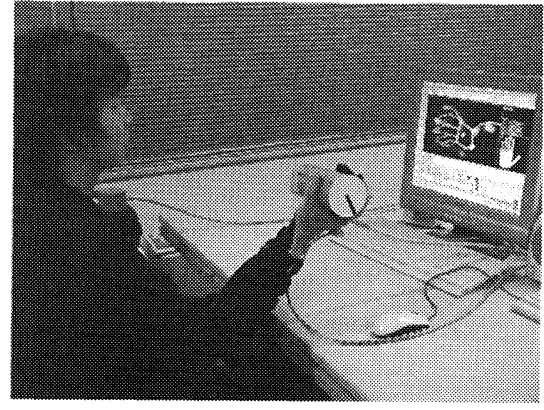

Fig. 5 Snapshot of the experiment

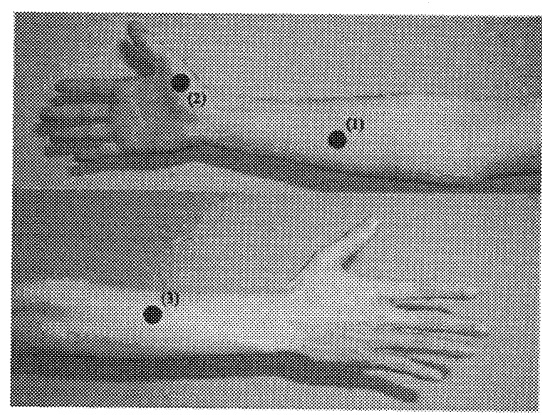

Fig. 6 Position of electrode for EMG measurement

と $b$ の持ち替えはこれらの代表的な把握状態の移行に よって構成されている. また, タスク $c$ は図 2 は円筒 軸を中心とする回転操作である. これは 3 章に示す理 由により, 図 2 の $\mathrm{x}$ 軸と円筒軸が常に平行に保たれる タスクを対象とし, 回転軸が限定されるためである. 同じ回転軸を持つ逆回転の操作に関しては, 前報(2)の 実験結果で他のタスクと比較して指の軌道のバラツキ が多く, 本システムでは認識率が悪かったため今回は 対象から外している. 実験前に各被験者の手の寸法を 計測し, 手形状による個人差を無くすことで純粋な接 触状態の検出が行えるよう, リンクモデルのスケール 調整を行っている. 手厚や手の甲の傾斜角も個人差が あるため Polhemus の初期調整を行っている.

タスク $a$ と $b$ は互いに逆の行程であるため, 交互に 試行を繰り返すことで同時に実験を行う. タスク $a b$ の実験は 150 秒間続けて行う. 回転操作であるタスク cの実験は, 配線の都合上長時間続けることが出来な い. よってタスク $c$ の実験は 75 秒間続けて行う.

$4 \cdot 3$ 類似度の分散計測による慣れと疲れの検出 入カパターンとテンプレートの相関が高くなり, 連続 DPマッチングの出力が極小值をとる時, 操作が検出さ れる. 図 9 は代表的な一名の被験者がタスク $b$ を行っ た時の類似度をプロットしている. また, 図 10(a)(b) 及び図11(a) はそれぞれタスク $a b$ とタスク $c$ における 時間の経過に伴う分散の変化を示す．このグラフは各 


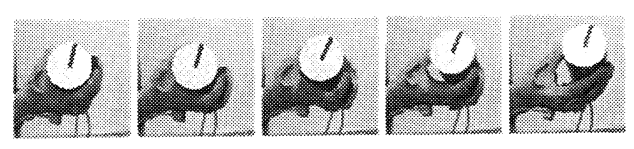

(a) Task a

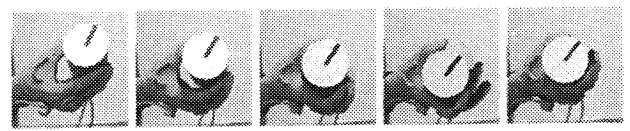

(b) Task b

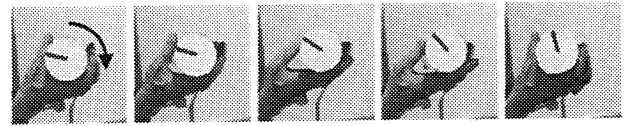

(c) Task c

Fig. 7 Sequential photographs of tasks

Task a :

31313131313129292929131313131313151599999999 Task b :

111111119999913131313131356777777313131313131 Task c :

$13151313 \quad 3 \quad 1515311111111111111999991115151313$

Fig. 8 Example of contact state sequences

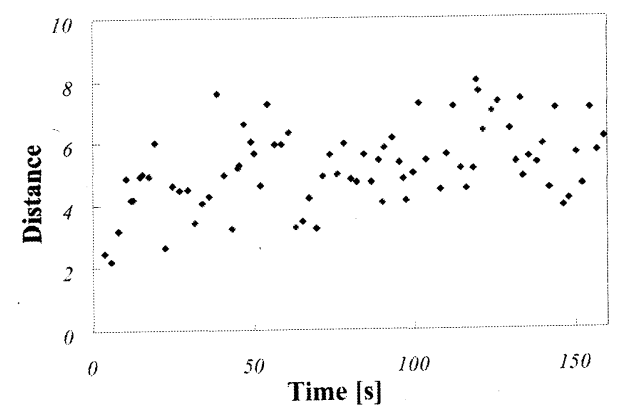

Fig. 9 Matching error (Task b)

類似度の点について前後それぞれ 10 サンプルの分散 を計算した結果を示している.ここで，グラフの y 軸 は2つのパターンの距離を表しており，この distance が小さくなると類似度は高くなることに注意されたい. 図 10(c) 及び図 11(b) はタスク $a b$ 及びタスク $c$ の長掌 筋における筋電図スペクトルの中間周波数の変化を示 している. なお，短拇指外転筋及び総指伸筋について は有意な傾向が見られなかった.

図 10(a)のタスク $a$ の結果を例にとると, 操作開始 から 35 秒まで分散が大きいことがわかる．本実験の タスクは, 日常的に見られる円柱の容易な操作である. 円柱の特性, 例えば大きさ, 重さ, 表面等に対して多 少の習熟期間は必要だが, 被験者は 35 秒程度の短時 間で習熟することは可能である. また, この分散はタ スクに適した操作戦略を試行錯誤する過程が起因する

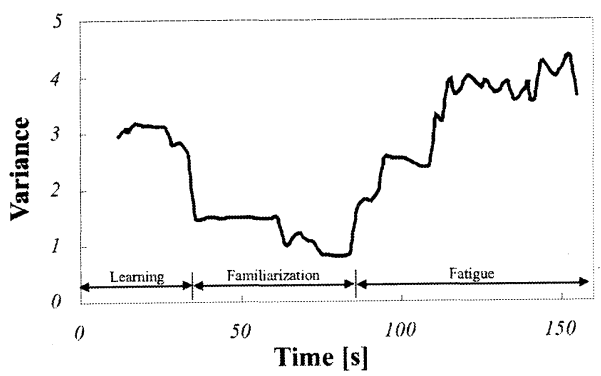

(a) Transition of variation (Task a)

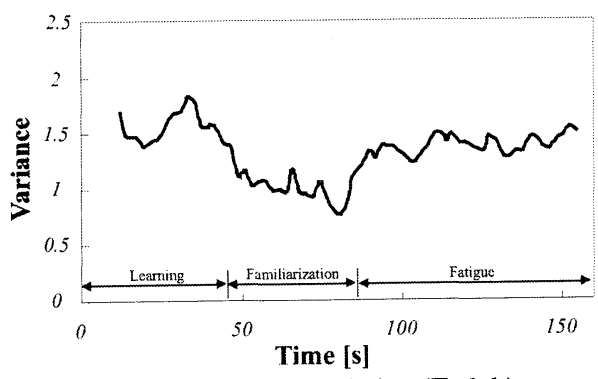

(b) Transition of variation (Task b)

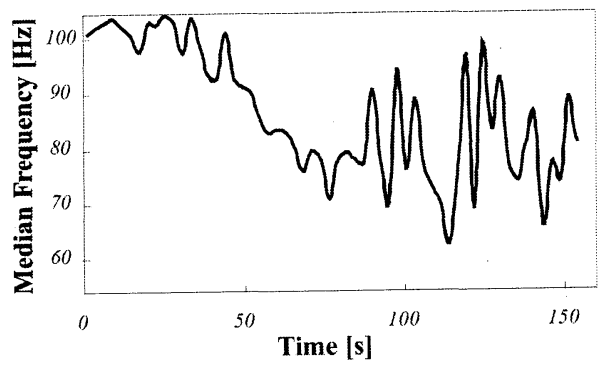

( (c) Median frequency of EMG (Tasks a and b)

Fig. 10 Variation and median frequency (Tasks $a$ and b)

と考察し, 被験者の操作は習熟期間にあると考える. 35 秒を経過すると分散は小さくなり, 接触状態遷移 パターンは一定に収束する。この小さい分散值は 85 秒まで継続され, 被験者はこの収束状態を維持し続け る.この時, 被験者は操作に対する習熟を終え, タス クに適した操作戦略が継続して実現されていると考察 する. 図 10(c) はタスク $a b$ の筋疲労の推移を示す. 操 作開始から 50 秒経過すると徐々に中間周波数が低下 し, 筋疲労が徐々に生じる様子がわかる. 筋疲労は増 加しつつ, ばらつきの少ない操作戦略を実現している ことから,この分散の収束は操作に対する慣れを表し ていると考察する.

図 10(a)に示す分散変化のグラフでは, 時間が 85 秒 を経過すると分散が再度大きくなる．この大きい分散 


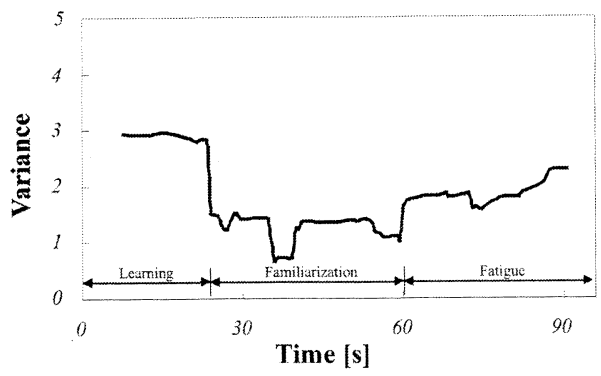

(a) Transition of variation

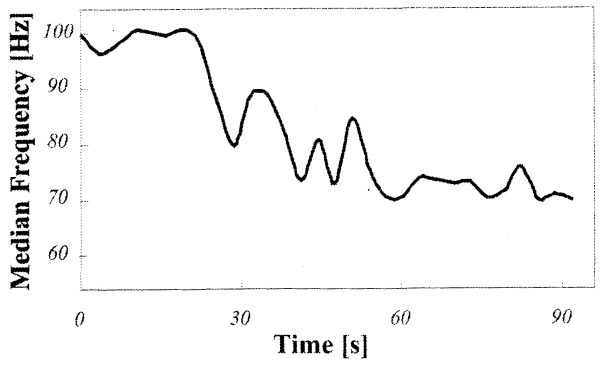

(b) Median frequency of EMG

Fig. 11 Variation and median frequency (Task c)

は操作終了まで継続する．被操作物体は $295 \mathrm{~g}$ の重さ を持つため, ほとんどの被験者が少し重いとの感想を 述べた. また, CyberGloveの表面は人の掌より滑りや すいため, 被験者は多少の違和感を感じた. この二つ の理由から, 遅くても 100 秒までには, 被験者は疲れ を訴えた．操作時間が十分経過すると, 被験者は手の 疲労によって適切な操作戦略が維持できなくなり, 負 荷は少ないがばらつきが大きい操作戦略へ移行すると 考察する. よって, この分散の拡大が疲れを表してい るといえる.

3つのタスクに共通してほぼ全ての実験結果が上記 の分散の傾向を持っており, 習熟・慣れ・疲れの3つ の時間帯に分けることができる. 図 10(a)(b) と図 11(a) には, 分割された 3 つの時間帯が示されている.この 分割は, 最も顕著に分散が変化している区間を抜き出 し，中央の時間を境界と判断した。

図 12 はタスク $a$ を行った時の 3 つ遷移パターンを 拔き出し，その詳細を示している．開始から (a)10.411.1[s], (b)72.3-72.9[s], (c)150.5-121.2[s]における遷 移パターンを示す．図12(a)に示すように操作直後は 接触状態 31(abcde) が観察されたが, 徐々に出現頻度 は減少し, 図 12(c)では全く出現しなくなった.この 状態 31 と入れ替わりで, 指中間部 (領域 b) が接触し ない接触状態 29(ab̄cde) の出現が增えた. タスク $b$ に 関しても同様の現象が確認された. 一方, タスク $c$ の

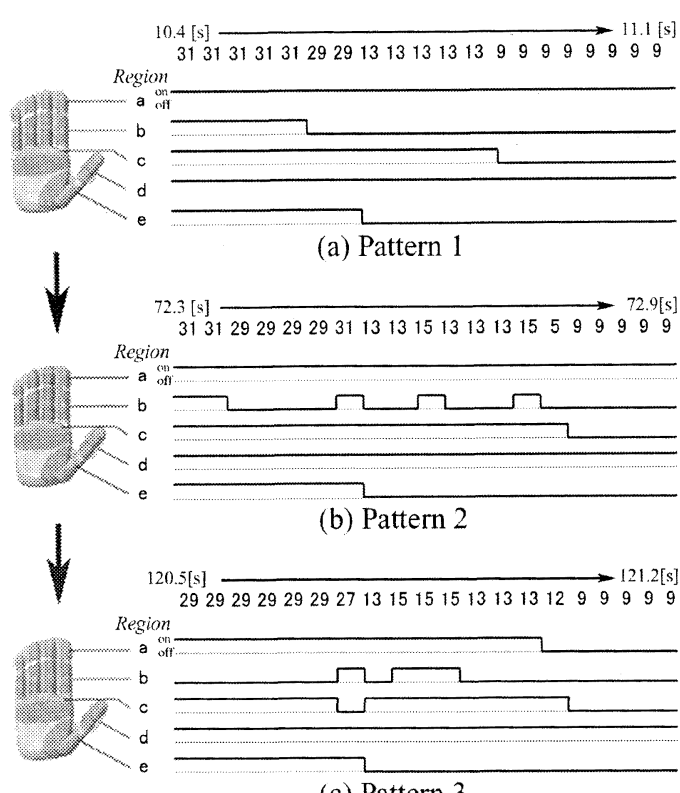

(c) Pattern 3

Fig. 12 Changing pattern of the contact state transition パターンは時間の経過に伴い, 接触領域数の少ない接 触状態の出現が増えた. 時間が経つと, 指を置き換え る直前に指先で回転力を加えて, 慣性を利用すること で楽に操作を行う傾向が見られた.

4.4 慣れの時間帯の操作からテンプレート生成 被験者が無意識的に目標の操作戦略を持ち, それを 目指して試行を繰り返すとすれば, 分散が小さくなる 慣れの時間帯の操作は, 目標に対してばらつきの少な い操作の集合と言える.この慣れの時間帯のデータか らテンプレートを生成することで, 目標から大きく誤 差を持つデータの混入を少なくすれば，より良い相関 計測の結果が得られると期待する. そこで, 事前に計 測した接触状態遷移パターンの平均を習熟・慣れ・疲 れの3つの時間帯に分けて計算することで各タスクに

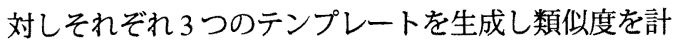
測する実験を行なった。

図13は，タスク aにおいて3つのテンプレートを用 いた時の時間に伴う類似度とその移動平均を示してい る.このグラフは各類似度の点について前後それぞれ 10 サンプルの平均を計算した結果を示している. テ ンプレート間の移動平均を比較すると, ほぼ同様の変 化を表している. 3 つの時間帯に分けたテンプレート の生成では単純に認識の類似度を向上させる結果は示 さなかった. 一方, Fig. 14 は，3つのタスクにおけ る時間に伴った類似度の分散の変化を示している. テ 


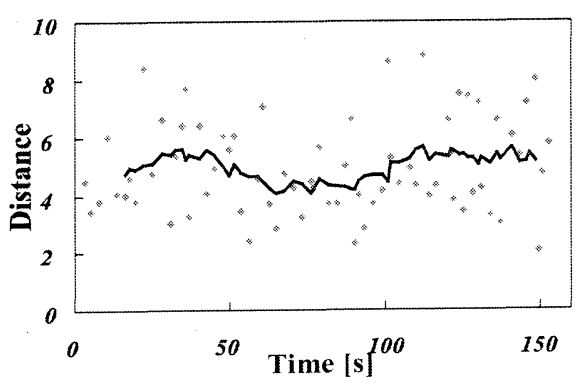

(a) Template generated by the proficiency term

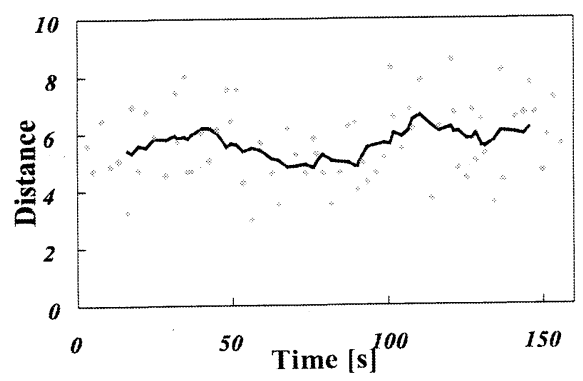

(b) Templete generated by the familiarization term

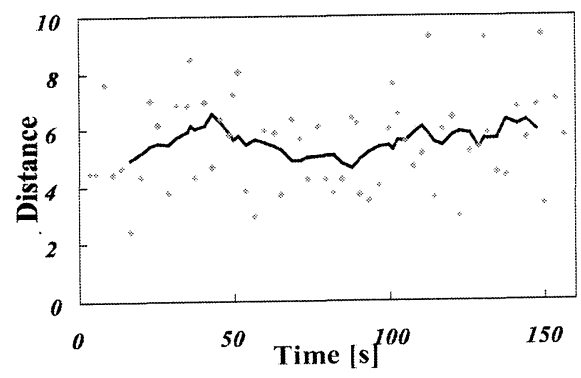

(c) Template generated by the fatigue term

Fig. 13 Similarity of input sequence in compatison with the three template (Task a)

ンプレート間の分散の変化を比較すると, 慣れのテン プレートにおける分散が終始低い值を示している. 他 の 2 つのタスクの結果にも同様の傾向が現れている. 分散が小さい慣れの時間帯での操作データを用いてテ ンプレートを生成することで, ばらつきを抑えた操作 認識が可能と言える. 全ての被験者において, 操作認 識のばらつきは平均 $42 \%$ 抑えられた.

4.5 考察 図10(c) はタスク $a b$ の筋疲労の推移 を示している. 操作開始から 45 秒経過すると徐々に 中間周波数が低下し, 筋疲労が生じている様子がわか る. 85 秒経過すると, 中間周波数は大きな振幅を伴う 振動が始まる．この結果はタスク $a b$ における分散の

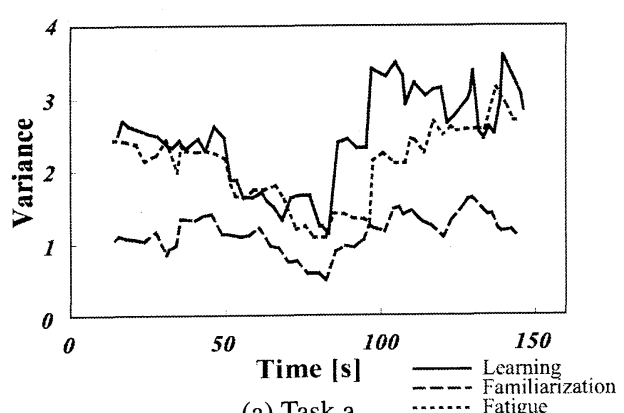

(a) Task a

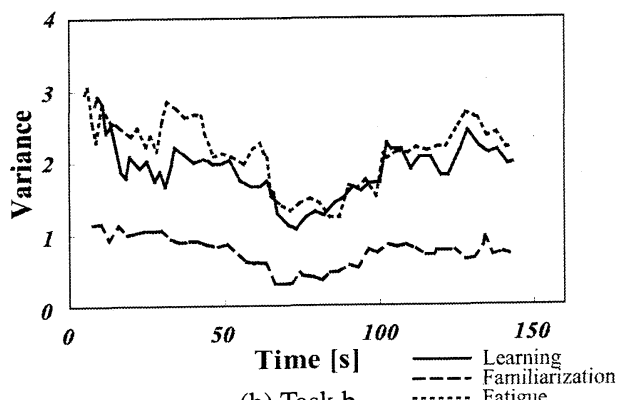

(b) Task b

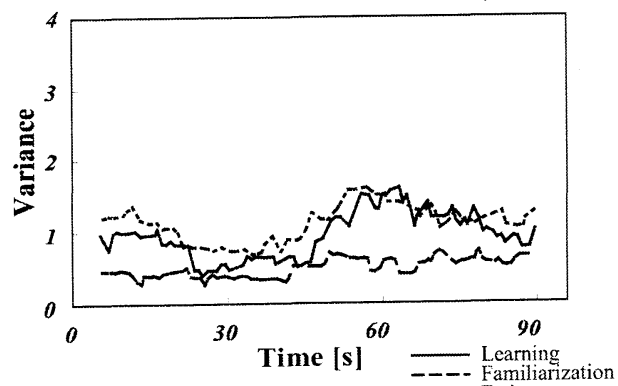

(c) Task c

Fig. 14 Variance with three model sequences

変化から分割した $3 つ の$ 時間帯とほぼ一致している. 後半以降に生じる中間周波数の振動は, タスク $a b$ に おいて 5 人中 3 人の被験者で観察された. しかし, タ スク $c$ ではこの現象は見られず，中間周波数の低下す る状態がそのまま続いた.

この中間周波数の振動は, 疲労によって誘発された 生理的振戦である. 振戦とは疲労によって手が震える 現象である．等尺性収縮で EMG を観測すると, 集中 的な筋放電と相対的に放電が小さい時間が, $10 \mathrm{~Hz}$ で 周期的に繰り返されることが知られている ${ }^{(15)}$. この 2 種類の放電時間では筋電図スペクトル分布が異なる ため, かつ周波数解析のための切り出し方による影響 で中間周波数に振動が発生する.よって, 振動の有無 
に関わらず, 分散変化のグラフから得られた疲労の時 間帯においては, 筋電データは大きい筋疲労を示して いる.

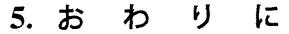

本稿では，慣れや疲れを考慮した操作認識のための テンプレート生成について調べた. まず, 接触状態遷 移の変化を用いて操作を認識する手法を紹介した. こ の手法を用いて, 円柱物体を用いた複数の操作につい て計測実験を行い, 時間の経過に伴う操作のばらつき の変化を計測し，被験者の操作に対する慣れや疲れの 検出を行った. また，操作を習熟・慣れ・疲れの $3 つ$ の時間帯に分割し, 各時間帯毎に 3 つのテンプレー トを生成することで入力操作との相関を計測した. そ の結果, 類似度の分散が習熟・慣れ・疲れにより変化 し，慣れの区間で分散が小さくなることを確認した. また，慣れの区間から生成されたテンプレートが，ば らつきを平均 $42 \%$ 抑えた操作認識を可能にすること を示した.

今後の課題としては, 慣れの時間帯の自動抽出が挙 げられる. 最終的には, 分散から慣れの抽出を行い, 標準パターンを自動で生成させることが望ましい. そ のためには, 3つの時間帯の境界線を発見する必要が あるため, さらに多くの操作データを取得し解析を行 なう予定である.

\section{文献}

(1) S.B.Kang, K.Ikeuchi: "Toward Automatic Robot Instruction from Perception-Temporal Segmentation of Tasks from Human Hand Motion", IEEE Trans. on Robotics and Automation, Vol. 11, No. 5, pp. 670-681, 1995.

(2) M.Kondo, J.Ueda, Y.Matsumoto, T.Ogasawara: "Perception of Human Manipulation Based on Contact State Transition", Proc. of the IEEE Int. Conf. on Intelligent Robots and Systems, pp.100-105, 2004.

(3) Jing Z.Liu, Te H.Dai, Vinod Sahgal, Robert W.Brown, Guang H.Yue: "Nonlinear Cortical Modulation of Muscle Fatigue: a Functional MRI Study", Brain Research, Vol.973, No.2, pp.320-329, 2002.

(4) Ming-I Lin, Huey-Wen Liang, Kwan-Hwa Lin, YawHuei Hwang: "Electromyographical Assessment on Muscular Fatigue - an Elaboration upon Repetitive Typing Activity", J. of Electromyogr. and Kinesiol., Vol.14, No.6, pp.661-669, 2004.

(5) H.Taguchi, K.Hase, T.Maeno: "Analysis of the Motion Pattern and the Learning Mechanism for Manipulating Objects by Human Fingers", Trans. of the Japan Society of Mechanical Engineers, Series C, Vol.68, No.670, pp.1647-1654, 2002.

(6) H.Kawasaki, K.Nakayama, G.Parker: "Teaching for Multi-Fingered Robots Based on Intention of Motion In Virtual Reality", Proc. of the Int. Conf. of the IEEE Industrial Electronics Society, pp.427-433, 2000.
(7) H.Ogata, T.Takahashi: "Robotic Assembly Operation Teaching in a Virtual Environment", IEEE Trans. on Robotics and Automation, Vol. 10, No. 3, pp. 391-399, 1994.

(8) J.Aleotti, S.Caselli, M.Reggiani: "Toward Programming of Assembly Tasks by Demonstration in Virtual Environment", IEEE Workshop on Robot and Human Interactive Communication, 2003.

(9) K.Ogawara, J.Takamatsu, H.Kimura, K,Ikeuchi: "Generation of a task model by integtating multiple observations of human demonstrations", Proc. of the IEEE Int. Conf. on Robotics and Automation, pp.1545-1550, May, 2002.

(10) Y.Kuniyoshi, Masayuki Inaba, Hirochika Inoue: "Learning by Watching: Extracting Reusable Task Knowledge from Visual Observation of Human Performance", IEEE Trans. on Robotics and Automation, Vol.10, No.6, pp.799-822, 1994.

(11) J.Case-Smith, C.Pehoski: "Development of Hand Skills in the Child", American Occupational Therapy Association, 1992.

(12) T.Nishimura, H.Yabe, R.Oka: "A Method of Model Improvement for Spotting Recognition of Gestures Using an Image Sequence", New Generation Computing, Vol.18, No.2, pp89-101, 2000.

(13) M.R.Cutkosky, R.D.How: "Human Grasp Choice and Robotic Grasp Analysis", Dextrous Robot Hand, Springer-Verlag, pp. 5-31, 1990.

(14) K.Ju, C.Lee, H.Minamitani, S.Onishi, H.Yamazaki: "Analysis of Muscle Fatigue during Repeated Dynamic Movement - Characteristics of Median Frequency of EMG and Blood Lactate Concentration -", Trans. of the Institute of Electronics, Information and Communication Engineers, D-2, Vol.J74, D-II, No.8, pp.1098-1107, 1991.

(15) K.Sakamoto, T.Yamaji, H.Makabe, M.Takanokura, H.Shimada, K.Mito: "Study of Evaluation of Function of Joint with Use of Physiological Tremor - Evaluation Concerning to Joints of Shoulder and Knee -", Proceedings of Meeting of Japan Ergonomics Research Society, pp.418-419, 2004. 